\title{
Operations Management for Business Startups "Jamu Partnership" in Indonesia
}

\author{
Supriyanto $^{1}$, Rhian Indradewa ${ }^{2}$, Tantri Yanuar Rahmat Syah $^{3}$, Diana Fajarwati ${ }^{4}$ \\ 1,2,3,4 Department Management, Faculty Economic and Business, Esa Unggul University, Jakarta - Indonesia \\ Corresponding Author: Supriyanto
}

\begin{abstract}
Background - Indonesian people's concern for health is increasing, this is marked by the implementation of a healthy lifestyle, namely more and more people, who do exercise, maintain their diet and desire to consume health drinks, one of which is Jamu. Jamu is an Indonesian heritage that has been passed down and is believed to be an effort to maintain fitness. To increase the consumption of jamu, efforts are made, one of which is health and fitness tourism in the form of jamu cafes. Jamu cafes are still limited in scope and information about jamu cafes serving delicious herbs is also difficult to access. The business of providing jamu cafes with a partnership system is a promising business opportunity by implementing effective and efficient operational management.
\end{abstract}

Method - Operations management effective, efficient and productive.

Result - This activity helps jamu partnership startup companies to carry out management operations appropriately.

Keywords: Operations Management, Startups, Jamu Partnership, Business Opportunity, Indonesia.

\section{INTRODUCTION}

As a startup company, PT OAM (PT Oesodo Alam Mandiri) is engaged in jamu partnerships. This startup company is the answer to the existence of business opportunities due to the increasing desire for entrepreneurship and the trend of healthy lifestyles of society in Indonesia. One of the lifestyles that is very popular in Indonesia today is the culture of drinking jamu which also gets support from the government. Jamu is one type of drink and traditional medicine in Indonesia.

Based on survey data, $73 \%$ of Indonesian people are very concerned about health. In addition, people's desire to become entrepreneurs is also very high, this can be seen by the increase in SMEs by $2.8 \%$ every year. As a new startup company, of course PT OAM requires good operations management. This is necessary so that the company can operate effectively and efficiently.

A good operational management system will support the sustainability of the company's business going forward, both in the process of competing with existing companies or companies that just emerge later. PT OAM's operations management will be made as streamlined as possible, of course in accordance with the goals that the company wants to achieve. Each operations management target is made in detail so that control in achieving operations performance can also be carried out easily, including the company will also be easy to make adjustments if there are deviations in the company's operational activities. Operations management of PT OAM as a jamu partnership startup is prepared according to the following discussion.

\section{MATERIALS AND METHODS}

In the current era of globalization, startup companies must be able to operate effectively and efficiently. Operational management needs to be structured properly 
so that make companies to be scalable, repeatable, and profitable the business model (Blank, G. and Dorf, 2012). PT OAM operations management as a series of activities that create value in goods and services by converting inputs into outputs (Heizer, 1988). Shown in Figure 2.1 below.

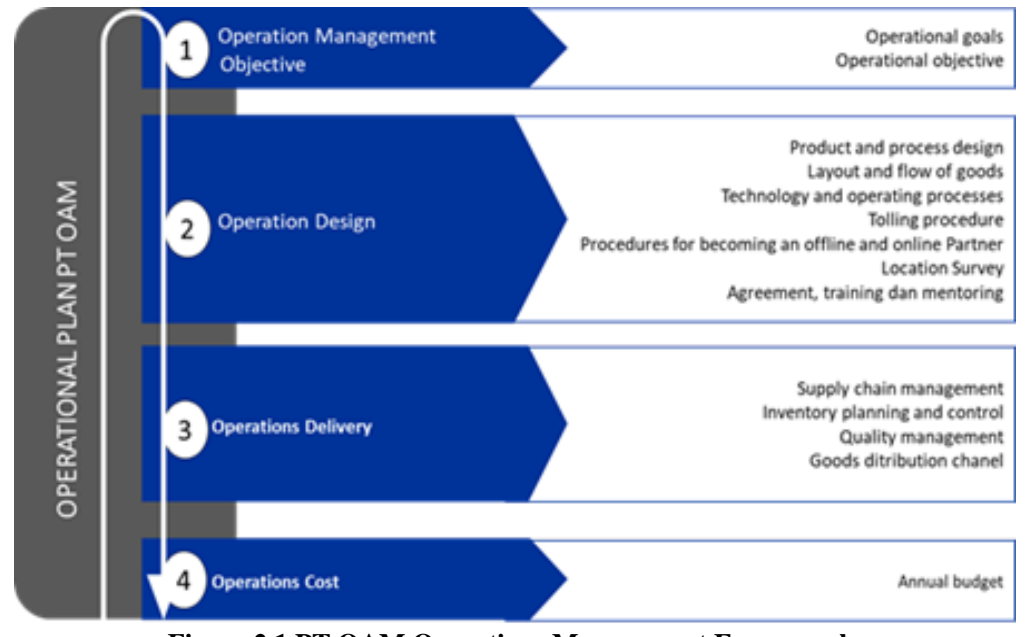

Figure 2.1 PT OAM Operations Management Framework.

Source: Author, 2021.

\section{Operations Management Objective}

Operations management objectives are arranged so that each activity is directed according to PT OAM's targets. In the implementation of PT OAM's goals, it must be able to stimulate managers and employees throughout to work with pride and enthusiasm to achieve the goals that have been set (David, 2011).

\section{Operations Design}

To remain competitive in the current era of globalization, PT OAM must be able to design and offer better products and services and be able to increase the efficiency of its operations (Taj \& Morosan, 2011). In addition, intense competition will force PT OAM to design and provide high quality products and services with minimal production costs (Paul, L.G. and Cho, 2011). So that the right operation design is very much needed by PT OAM, both the operation design for the product and also the business partnership. In product and partnership development operations, PT OAM collaborating with other companies in development is often seen as a way to access new technologies (Lambe, Spekman, \& Hunt, 2002).

\section{Operations Delivery}

PT OAM's delivery of operations consists of supply chain, inventory and quality management. PT OAM's needs to design and ensure that supply chain management in its business runs well. Supply chain management is very important in integrating key business processes with suppliers and customers. So that existing products, services, and information can add value to all stakeholders (Croxton et al., 2001). The goal of PT OAM supply chain management is to ensure that each entity in the supply chain provides each other with the latest information so as to create a perfect balance between supply and demand. One of the criteria for PT OAM's partner companies in terms of supply chains is the location of the company. A close location will have an impact on the effectiveness of the company and can reduce the company's operational costs (Ramadhan et al., 2020).

PT OAM's inventory management is designed to ensure that goods are always available and at the same time minimize expiration times (Nahmias, 1982). Because inventory management is one of the factors that can affect the company's performance (Ahmad \& Zabri, 2016). So the 
management of PT OAM needs to carry out strict calculations and control over the products owned by the company. In managing inventory, PT OAM also needs to determine a clear standard operating procedure (SOP). SOPs are important for controlling processes within the company (Frau \& Lutz, 2014). In addition, in the era of globalization, PT OAM will experience a lot of competition. In order to survive in today's business environment, companies need to find ways to improve quality and maintain their competitive advantage (Tan, Lin, \& Hung, 2003). PT OAM needs to provide a different quality product compared to existing products on the market. This is because differentiators are needed both in terms of price, taste and quality (Naim et al., 2020). One way that PT OAM does to ensure quality is by conducting product inspections. This visual inspection of the product is used to determine whether a product either partially or wholly deviates from specifications or not (Sablatnig, 1997). Quality management activities are also carried out with customer satisfaction surveys in collaboration with PT OAM. Customer satisfaction is an assessment of the comfort made by customers after getting company services (Taryana et al., 2021). In the company's operational activities, PT OAM will also carry out product development on an ongoing basis. Where the development of this product will involve supplier companies and customers of PT OAM. This is so that product development can be faster and more efficient if it is done within a network of companies, suppliers and customers (Clark, 1989).

\section{Operations Cost}

PT OAM prepares operating costs for the next five years. Operating capital costs should always be based on the level of organizational needs (Baldenius, T., Dutta, S., \& Reichelstein, 2007).

\section{DISCUSSION}

The jamu partnership business that PT OAM is planning, of course requires the right operational strategy, in managing and building the company going forward, operations management objectives, operating design, operations delivery and operations budget, so that the company will be able to compete well in the industry and jamu product market in Indonesia.

\section{Operations Management Objective}

PT OAM develops operational objectives through several stages, as shown in the tabel 3.1 below

Tabel 3.1 Operational Management Objective

\begin{tabular}{|c|c|}
\hline Category & Goal Content \\
\hline \multirow{3}{*}{$\begin{array}{l}\text { Short-term } \\
\text { (Y.0 to }<Y .1)\end{array}$} & 1. Do tolling cooperation \\
\hline & 2. Do Product Development. \\
\hline & 3. Provide infrastructure facilities for jamu partnerships \\
\hline \multirow{3}{*}{$\begin{array}{c}\text { Mid-term } \\
\text { (Y1 to Y2) }\end{array}$} & 1. Opened a representative for PT OAM on the island of Java \\
\hline & 2. Established cooperation with shipping companies in inter-province on the island of Java. \\
\hline & 3. Provide data server base \\
\hline \multirow{3}{*}{$\begin{array}{l}\text { Long-term } \\
\text { (Y>2) }\end{array}$} & 1. Implement quality management on an ongoing basis \\
\hline & 2. Opened representatives of PT OAM outside Java \\
\hline & 3. Establish cooperation with inter-provincial shipping companies outside Java \\
\hline
\end{tabular}

\section{Operations Design}

An important decision in operations management is to determine what kind of product design and operations the company will produce. PT OAM focuses on jamu product design and jamu partnership design. PT OAM continues to develop with old products, increase usability, add variants 
and designs of product packaging. In conducting product development through the following stages:

a. Determine product variants.

Determine product variants or new designs that will be developed or used as new PT OAM products.

b. Determine the formula.

After the evaluation has made a decision that a new type of product variant can be produced, a formula for the product to be made is immediately made.

c. Make a product sampling.

After the formula has been determined, the product sampling is continued.

d. Distribute product sampling.

Distribute new product samples to several respondents to assess whether the new product produced can be accepted by the customer.

e. Conduct an evaluation.

Evaluate the responses given by the respondents, if the results of the product evaluation can be accepted by the customer, then proceed to the production process of the new product.

f. Production of products.

Every product that is ready for production with the brand, design and formula is sent to the tolling place from PT OAM to be produced. Here are some examples of jamu products and jamu package partnership on Figure 3.1 and 3.2 below.
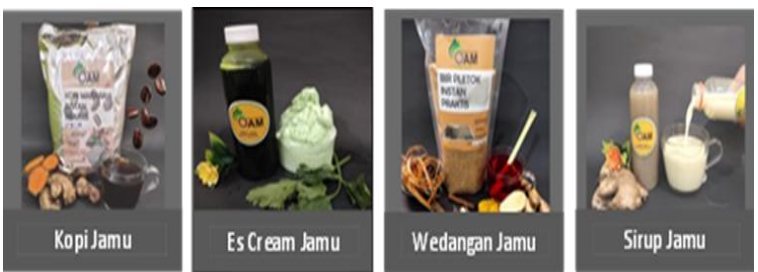

Figure 3.1 PT OAM Design Product Jamu. Source: Author, 2021.
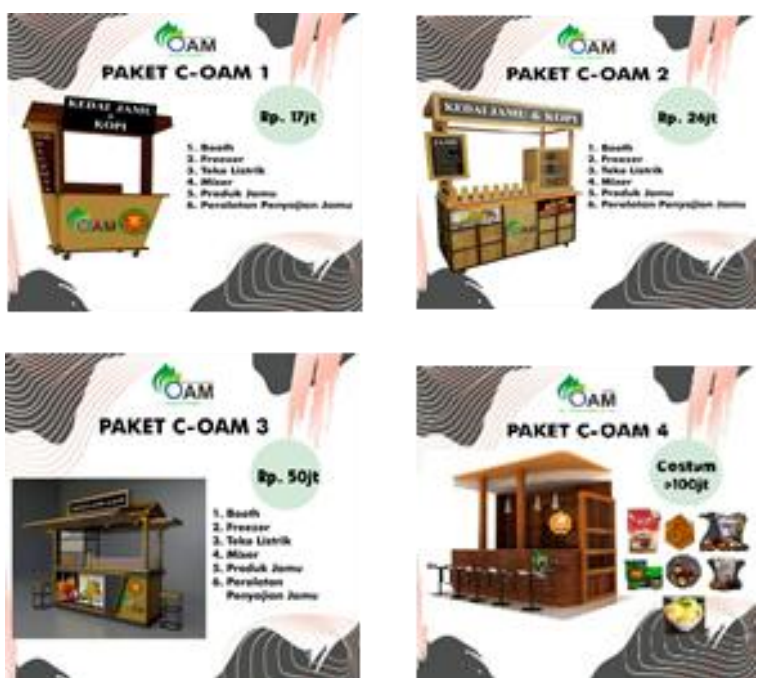

Figure 3.2 PT OAM Design Jamu Package Partnerships. Source: Author, 2021.

In addition to product design, PT OAM makes a process design with the aim of knowing the stages of the process to produce jamu products and jamu partnership packages. Process design for jamu products with tolling and jamu partnerships, as show in Figures 3.3, 3.4 and 3.5 below :

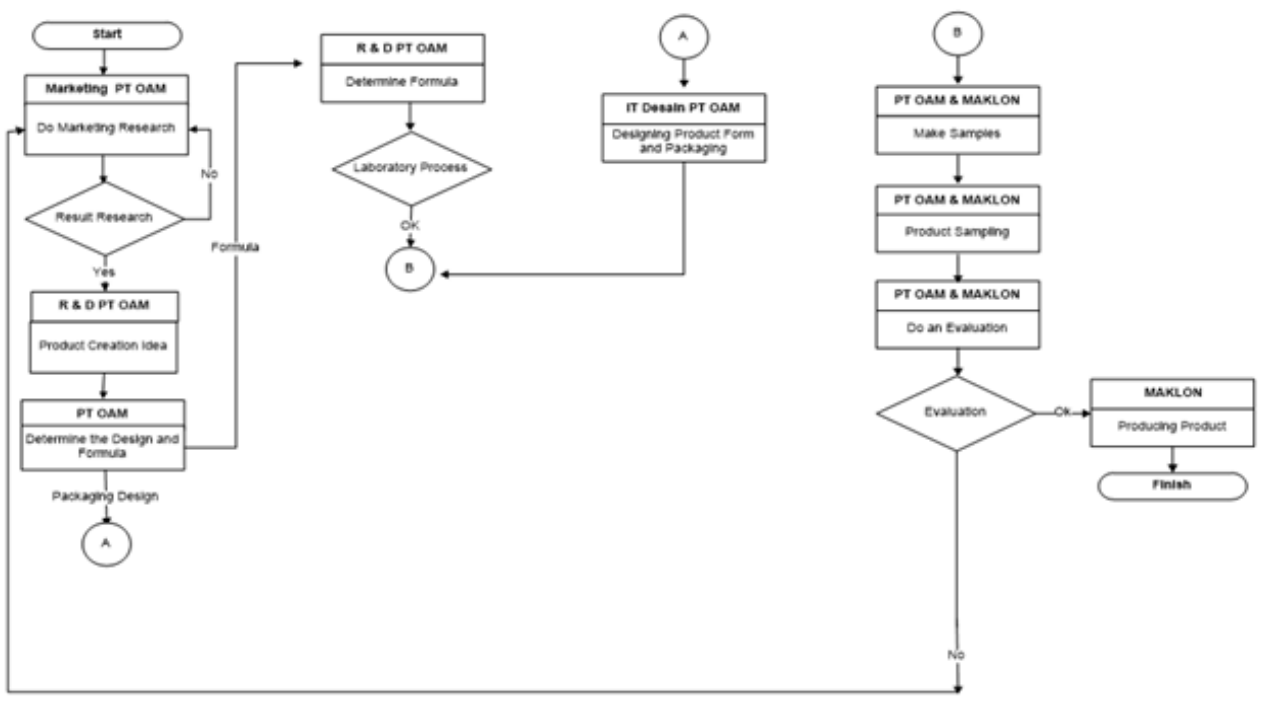

Figure 3.3 PT OAM Design Process Jamu Product

Source: Author, 2021 

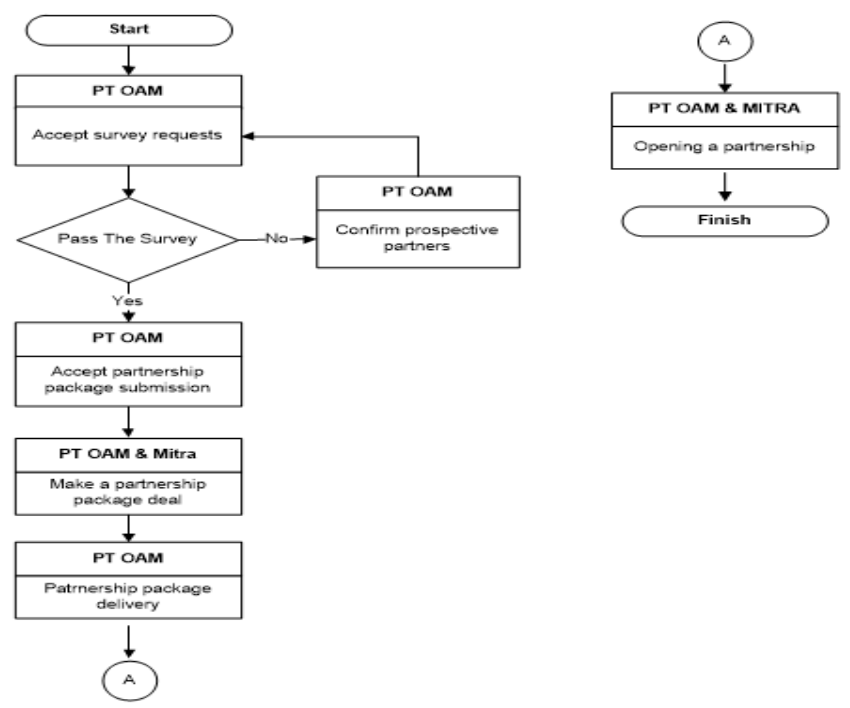

Figure 3.4 PT OAM Design Process Jamu Partnerships Source: Author, 2021

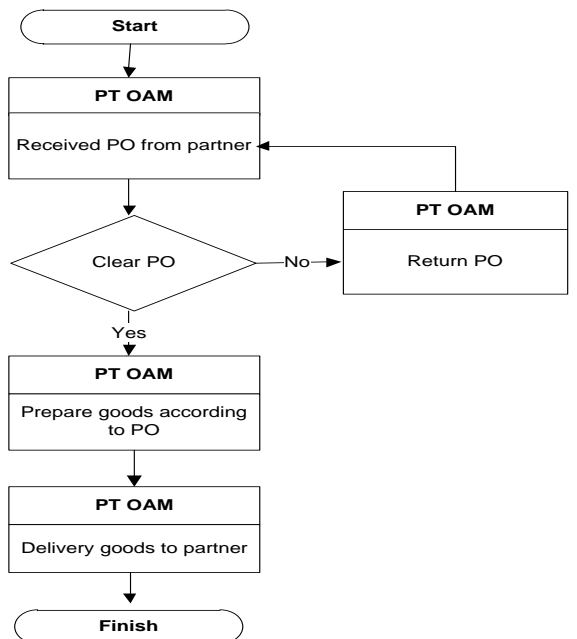

Figure 3.5 PT OAM Design Repeat order Jamu Source: Author, 2021.

Machine technology and a laboratory for making herbal medicine are prepared at the toll booth, while for the jamu partnership after becoming a partner of PT OAM, training and partner assistance will be provided. PT OAM for the procurement of goods is carried out at the toll booths and the furniture industry, so that for the layout of production activities carried out at the toll booths, the layout of the operational processes starting from production, warehouses and others can follow the provisions of Good Traditional Medicine Manufacturing Practices (CPOTB), year 2011. PT OAM has an office as the center of operational activities and has offices for several departments; the concept of the room is an open model with no inter-departmental barriers, for that it is necessary to determine the right seating layout so that it can facilitate communication and efficiency, lay out offices PT OAM in figure 3.6 below:

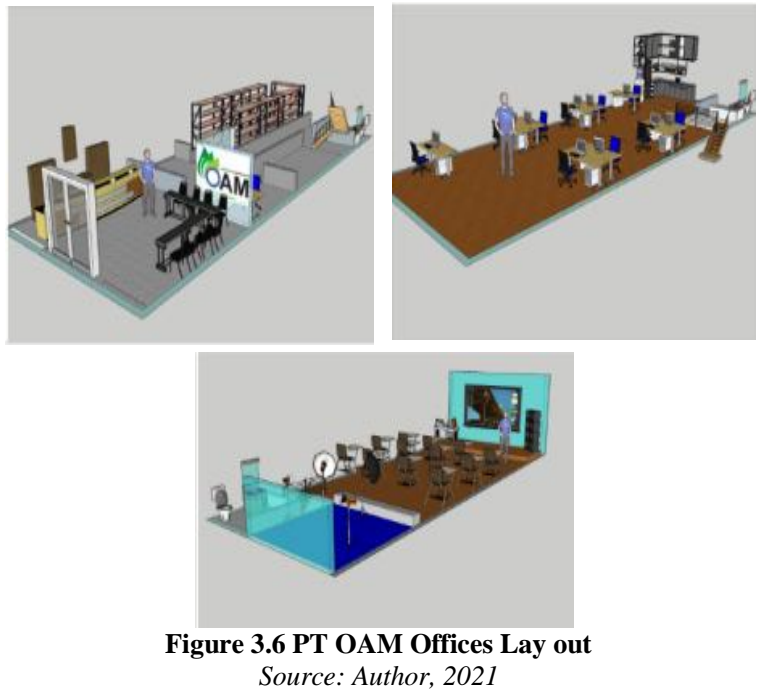

\section{Operations Delivery}

Operational delivery at PT OAM includes supply chain management, inventory planning and control, quality management and distribution channels.

The main goal of supply chain management at PT OAM is to deliver products to consumers on time to satisfy customers, reduce production costs, increase quality results, time efficiency and distribution planning to customers. The supply chain of PT OAM is the toll industry 
and the furniture industry, the toll industry is very dependent on several suppliers of raw materials, packaging materials, other auxiliary materials and suppliers of production machines in producing jamu products so that they can meet the demand for jamu products for PT OAM. Meanwhile, to produce jamu partnership package products in the form of booths and accessories, PT OAM has a furniture industry supplier that relies heavily on wood shops, paint shops, glass shops and banner printing shops.

PT OAM is a company whose products are obtained from suppliers in the form of finished goods, for that PT OAM only controls the inventory of goods or finished products in the form of jamu products with many variants and finished goods in the form of jamu partnership products, namely booths with completeness, while planning and inventory control is carried out following the forecast of annual sales that are assumed to be in monthly inventory. The following table 3.2 shows the planning and control of PT OAM's inventory within 5 years.

Tabel 3.2 Assumption of monthly inventory of PT OAM

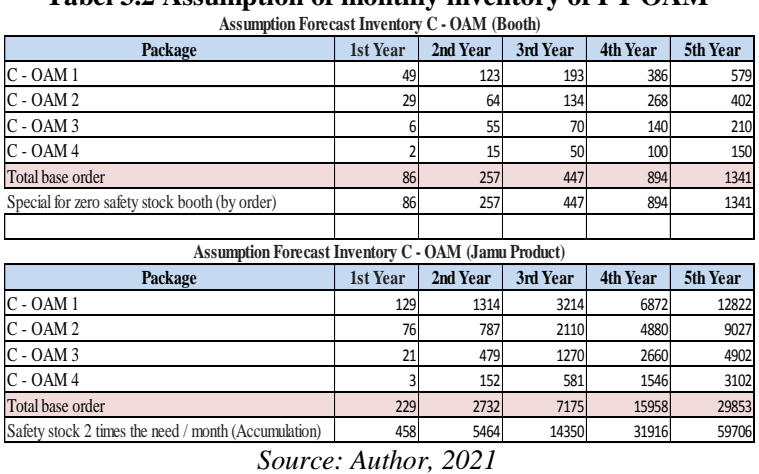

In quality control, PT OAM focuses on inspection of goods coming from suppliers, handling stock of goods and checking goods out before reaching the customer, besides that PT OAM conducts customer satisfaction surveys after every transaction to get feedback from customers on the products and services that PT OAM has provided. The distribution channel of goods from PT OAM is a direct distribution channel, namely goods from PT OAM directly sent to partners, through the product purchase order process, both for partnership package products or repeat orders for jamu products.

\section{Operations Cost}

The operating cost budget assumptions at PT OAM are divided into 3 groups:

a. Pre-operation costs consist of building renovation costs, permits, cafe displays and consultants incurred prior to the establishment of PT OAM.

b. Asset costs, namely costs for purchasing goods needed for the office such as operational cars, delivery box cars, laptops, tables and chairs, warehouse shelves and others. The cost of this asset is assumed for 4 years from the first year and will be purchased in the 5th year assuming an increase of 5\%.

c. Operational costs are costs that are issued regularly to support PT OAM's operational activities such as electricity costs, telephone costs, water costs and others. The assumption of this operational cost is for costs that are paid once a year to be paid at the beginning of the year such as zoom fees, vehicle insurance costs, while for costs that are paid monthly and for cost increases every year from year 1 to year 5 are added. 5\% increase.

\section{CONCLUSION}

The jamu partnership business is a potential business opportunity in Indonesia with the implementation of appropriate operational management through quality management, product and process design, layout, supply chain management, inventory planning and control as well as appropriate distribution channels oriented towards effectiveness and efficiency as well as productivity, will bring this business to compete and develop well.

\section{Acknowledgement: None}

Conflict of Interest: None 


\section{Source of Funding: None}

\section{REFERENCES}

1. Ahmad, K., \& Zabri, S. M. (2016). Inventory management practices among Malaysian micro retailing enterprises. Journal of Business and Retail Management Research, 11(1), 103-115.

2. Baldenius, T., Dutta, S., \& Reichelstein, S. (2007). Cost allocation for capital budgeting decisions. The Accounting Review, 82(4), 837-867..pdf.

3. Blank, G. and Dorf, B. (2012). The Startup Owner's Manual-The Step-by-Step Guide for Building a. Blank, G. and Dorf, B.

4. Clark, K. B. (1989). Project Scope and Project Performance: The Effect of Parts Strategy and Supplier Involvement on Product Development. Management Science, 35(10), 1247-1263.

5. Croxton, K. L., García-Dastugue, S. J., Lambert, D. M., \& Rogers, D. S. (2001). The Supply Chain Management Processes. The International Journal of Logistics Management, 12(2), 13-36. https://doi.org/10.1108/0957409011080627 1.

6. David, F. R. (2011). Strategic Management: Concepts and Cases. Thirteenth, Global Edition.

7. Frau, B. A., \& Lutz, J. (2014). Committee of Sponsoring Organizations of the Treadway Commission: Internal Control Integrated Framework mit besonderer Berücksichtigung der Änderungen in der Neuauflage 2013. Institute for Technology and Knowledge Transfer, 1-106.

8. Heizer, J. (1988). Operations Management 12Ed. In Management Decision (Vol. 26). https://doi.org/10.1108/eb001490.

9. Lambe, C. J., Spekman, R. E., \& Hunt, S. D. (2002). Alliance competence, resources, and alliance success: Conceptualization, measurement, and initial test. Journal of the Academy of Marketing Science, 30(2), 141158. https://doi.org/10.1177/03079459994399.

10. Nahmias, S. (1982). "Perishable inventory theory: a review", Operations Research, Vol. 30, pp. 680-708.
11. Naim, A., Syah, T. Y. R., Pusaka, S., \& Ramdhani, D. (2020). Implementation of Quality Management for Food Combining on Startup Business PT. Beras Jagung Nusantara. Journal of Multidisciplinary Academic, 3(5), 151-155.

12. Paul, L.G. and Cho, B. R. (2011). "The development of multi- response experimental designs for process parameter optimization", International Journal of Quality \& Reliability Management, Vol. 28 No. 6, pp. 628-648.

13. Ramadhan, R., Syah, T. Y. R., Indradewata, R., \& Fajarwati, D. (2020). Determination of Factory Location PT . Kelola Lingkungan Kita Using Factor Rating. Journal of Multidisciplinary Academic, 04(32), 435438.

14. Sablatnig, R. (1997). A Highly Adaptable Concept for Visual Inspection Acknowledgments.

15. Taj, S., \& Morosan, C. (2011). The impact of lean operations on the Chinese manufacturing performance. Journal of Manufacturing Technology Management, 22(2), 223-240. https://doi.org/10.1108/1741038111110223 4.

16. Tan, B., Lin, C., \& Hung, H. C. (2003). An ISO 9001:2000 quality information system in e-commerce environment. Industrial Management and Data Systems, 103(8-9), 666-676. https://doi.org/10.1108/0263557031050608 9.

17. Taryana, T., Syah, T. Y. R., Fajarwati, D., \& Indradewa, R. (2021). Implementation of Operational Strategy Planning in Arena Corner Business. Journal of Multidisciplinary Academic, 118-123.

How to cite this article: Supriyanto, Indradewa $\mathrm{R}$, Syah TYR et.al. Operations management for business startups "jamu partnership" in Indonesia. International Journal of Research and Review. 2021; 8(8): 277-283. DOI: https://doi.org/10.52403/ijrr.20210838 